\title{
Neurite outgrowth mediated by the heat shock protein Hsp90 $\alpha$ : a novel target for the antipsychotic drug aripiprazole
}

\author{
T Ishima ${ }^{1}$, M lyo $^{2}$ and K Hashimoto ${ }^{1}$
}

Aripiprazole is an atypical antipsychotic drug approved for the treatment of psychiatric disorders such as schizophrenia, bipolar disorder, major depressive disorder and autism. The drug shows partial agonistic activity at dopamine $D_{2}$ receptors and 5-hydroxytryptamine (5-HT) 5- $\mathrm{HT}_{1 \mathrm{~A}}$ receptors, and antagonistic activity at 5- $\mathrm{HT}_{2 \mathrm{~A}}$ receptors. However, the precise mechanistic pathways remain unclear. In this study, we examined the effects of aripiprazole on neurite outgrowth. Aripiprazole significantly potentiated nerve growth factor (NGF)-induced neurite outgrowth in PC12 cells, in a concentration-dependent manner. The 5- $\mathrm{HT}_{1 \mathrm{~A}}$ receptor antagonist WAY-100635, but not the dopamine $\mathrm{D}_{2}$ receptor antagonist sulpiride, blocked the effects of aripiprazole, although, only partially. Specific inhibitors of inositol 1,4,5-triphosphate $\left(\mathrm{IP}_{3}\right)$ receptors and BAPTA-AM, a chelator of intracellular $\mathrm{Ca}^{2+}$, blocked the effects of aripiprazole. Moreover, specific inhibitors of several common signaling pathways phospholipase C- $\gamma$ (PLC- $\gamma$ ), phosphatidylinositol-3 kinase (PI3K), mammalian target of rapamycin, p38 MAPK, c-Jun N-terminal kinase, Akt, Ras, Raf, ERK, MAPK) also blocked the effects of aripiprazole. Using proteomic analysis, we found that aripiprazole significantly increased levels of the heat shock protein Hsp90 $\alpha$ in cultured cells. The effects of aripiprazole on NGF-induced neurite outgrowth were significantly attenuated by treatment with Hsp90 $\alpha$ RNA interference, but not by the negative control of Hsp90a. These findings suggest that both $5-\mathrm{HT}_{1 \mathrm{~A}}$ receptor activation and $\mathrm{Ca}^{2+}$ signaling via $\mathrm{IP}_{3}$ receptors, as well as their downstream cellular signaling pathways play a role in the promotion of aripiprazole-induced neurite outgrowth. Furthermore, aripiprazole-induced increases in Hsp90 $\alpha$ protein expression may form part of the therapeutic mechanism for this drug.

Translational Psychiatry (2012) 2, e170; doi:10.1038/tp.2012.97; published online 16 October 2012

\section{Introduction}

Aripiprazole is an atypical antipsychotic drug, approved for the treatment of schizophrenia, acute manic or mixed episodes associated with bipolar I disorder, as an adjunct treatment for major depressive disorder, and for irritability in children with autism. ${ }^{1-9}$ Aripiprazole shows high affinity at dopamine $D_{2}$, and $\mathrm{D}_{3}$ receptors, 5-hydroxytryptamine $(5-\mathrm{HT}) 5-\mathrm{HT}_{1 \mathrm{~A}}$, and $5-\mathrm{HT}_{2 \mathrm{~A}}$ receptors, and moderate affinity at dopamine $\mathrm{D}_{4}$ receptors, $5-\mathrm{HT}_{2 \mathrm{C}}$ receptors, $\alpha_{1}$ adrenergic receptors and histamine $\mathrm{H}_{1}$ receptors. ${ }^{10,11}$ While it is known that aripiprazole is a partial agonist at dopamine $\mathrm{D}_{2}$ and $5-\mathrm{HT}_{1 \mathrm{~A}}$ receptors and an antagonist at $5-\mathrm{HT}_{2 \mathrm{~A}}$ receptors, the precise mechanisms underlying its clinical efficacy in psychiatric disorders are unknown. ${ }^{12-14}$

Accumulating evidence suggests that at the cellular level, neuronal plasticity, such as neurite outgrowth and neuroprotection, underlie the therapeutic effect of atypical antipsychotic drugs. ${ }^{15-18}$ PC12 cells, a cell line derived from a pheochromocytoma of the rat adrenal medulla, are widely used as a model system for nerve growth factor (NGF)-induced neurite outgrowth. ${ }^{19-25}$ It is reported that atypical antipsychotic drugs such as olanzapine, quetiapine and clozapine could enhance neurite outgrowth in $\mathrm{PC} 12$ cells. ${ }^{15} \mathrm{~A}$ number of signaling molecules, including phospholipase C- $\gamma$ (PLC- $\gamma$ ), phosphatidylinositol-3 kinase (PI3K), the mammalian target of rapamycin (mTOR), p38 MAPK, c-Jun N-terminal kinase (JNK), Akt and the Ras/Raf/ERK/MAPK pathways plays a role in the NGFinduced neurite outgrowth in PC12 cells. ${ }^{19-25}$ To date, there are no reports on precisely how aripiprazole induces neurite outgrowth, although it is reported that this drug protects rat cortical neurons against glutamate toxicity. ${ }^{26}$

The purpose of this study was first to examine the effect of aripiprazole on NGF-induced neurite outgrowth in PC12 cells. We found that aripiprazole significantly potentiated NGFinduced neurite outgrowth. Second, we examined the role of intracellular $\mathrm{Ca}^{2+}$ and the endoplasmic reticulum (ER) protein inositol 1,4,5-triphosphate $\left(\mathrm{IP}_{3}\right)$ receptors, on the potentiation of NGF-induced neurite outgrowth by aripiprazole, since $\mathrm{Ca}^{2+}$ signaling via $\mathrm{IP}_{3}$ receptors plays an important role in NGF-induced neurite outgrowth. ${ }^{19-25}$ Third, we investigated the role of cellular signaling pathways on aripiprazole potentiation of NGF-induced neurite outgrowth. Finally, using proteomic analysis, we observed significantly increased levels of heat shock protein Hsp90 $\alpha$, one of the most abundant

${ }^{1}$ Division of Clinical Neuroscience, Chiba University Center for Forensic Mental Health, Chiba, Japan and ${ }^{2}$ Department of Psychiatry, Chiba University Graduate School of Medicine, Chiba, Japan

Correspondence: Professor K Hashimoto, Division of Clinical Neuroscience, Chiba University Center for Forensic Mental Health, 1-8-1 Inohana, Chiba 260-8670, Japan. E-mail: hashimoto@ faculty.chiba-u.jp

Keywords: aripirazole; $\mathrm{Ca}^{2+}$ signaling; heat shock protein; $\mathrm{IP}_{3}$ receptors; neurite outgrowth

Received 3 July 2012; revised 27 July 2012; accepted 25 August 2012 
proteins in cells, ${ }^{27-34}$ after treatment with aripiprazole and speculate that this protein may promote NGF-induced neurite outgrowth. Precise neurobiological functions of $\mathrm{Hsp} 90 \alpha$ in the brain are currently unknown although $\mathrm{Hsp} 90 \alpha$ protein is a ubiquitous and essential molecular chaperone that plays central roles in many signaling and other cellular pathways. $^{27-31}$

\section{Materials and methods}

Drugs. Drugs were obtained from the following sources: aripiprazole (Toronto Research Chemicals, North York, ON, Canada); xestospongin C (Wako Pure Chemicals, Tokyo, Japan); WAY-100635, and LY294002 (Sigma-Aldrich, St Louis, MO, USA); NGF (Alomone Labs, Jerusalem, Israel); 8OH-DPAT (( \pm )-8-hydroxy-2-dipropylaminotetralin hydrobromide), and sulpiride (Tocris Bioscience, Bristol, UK); lovastatin, PD98059, GW5074, SB203580, MEK1/2 inhibitor (SL327), SP600125, U0126, U0124, 2-aminoethoxydiphenyl borate (2-APB) and rapamycin (Calbiochem-Novabiochem, San Diego, CA, USA); Akt inhibitor (Bio Vision, CA, USA); and BAPTA-AM, 1,2-bis (2-aminophenoxy)ethane- $N, N, N^{\prime}, N$ '-tetraacetic acid tetrakis) acetoxymethyl ester, (Dojindo Molecular Technologies, Kumamoto, Japan). Other drugs were also purchased from commercial sources.

Cell culture and quantification of neurite outgrowth. PC12 cells (RIKEN Cell Bank, Tsukuba, Japan) were cultured at $37^{\circ} \mathrm{C}, 5 \% \mathrm{CO}_{2}$ in Dulbecco's modified Eagle's medium (DMEM), supplemented with $5 \%$ heat-inactivated fetal bovine serum (FBS), 10\% heat-inactivated horse serum and $1 \%$ penicillin. Medium was changed two to three times a week. PC12 cells were plated onto 24-well tissue culture plates coated with poly-D-lysine/laminin. Cells were plated at relatively low density $\left(0.25 \times 10^{4}\right.$ cells $\left.\mathrm{cm}^{-2}\right)$ in DMEM medium containing $0.5 \%$ FBS, $1 \%$ penicillin-streptomycin. Medium containing a minimal level of serum ( $0.5 \%$ FBS) was used as previously reported. ${ }^{19-25}$ Previously, we examined the optimal concentration of NGF needed to induce neurite outgrowth in PC12 cells, and found that NGF $(2.5,5,10,20$, $40 \mathrm{ng} \mathrm{ml}^{-1}$ ) increased the number of cells with neurite outgrowth in a concentration-dependent manner. ${ }^{19}$ In this study, $2.5 \mathrm{ng} \mathrm{ml}^{-1}$ of NGF was used to study the potentiating effects of aripiprazole on neurite outgrowth. Twenty-four hours after plating, the medium was replaced with DMEM medium containing $0.5 \% \mathrm{FBS}$ and $1 \%$ penicillin-streptomycin with NGF $\left(2.5 \mathrm{ng} \mathrm{ml}^{-1}\right)$, with or without aripiprazole $(0.001$, $0.01,0.1$ or $1.0 \mu \mathrm{M})$, WAY-100635 $\left(5-\mathrm{HT}_{1 \mathrm{~A}}\right.$ receptor antagonist; $10 \mu \mathrm{M}$ ), sulpiride (dopamine $D_{2}$ receptor antagonist; $10 \mu \mathrm{M})$, xestospongin $\mathrm{C}\left(\mathrm{IP}_{3}\right.$ receptor antagonist; $\left.1.0 \mu \mathrm{M}\right)$, 2-APB $\left(\mathrm{IP}_{3}\right.$ receptor antagonist; $\left.100 \mu \mathrm{M}\right)$, BAPTA-AM (a chelator of intracellular $\mathrm{Ca}^{2+} ; 5.0 \mu \mathrm{M}$ ) or selective inhibitors for cellular signal targets.

Four days after incubation with NGF $\left(2.5 \mathrm{ng} \mathrm{ml}^{-1}\right)$ with or without specified drugs, morphometric analysis was performed on digitized images of live cells taken under phasecontrast illumination, with an inverted microscope linked to a camera. Images of three fields per well were taken, with an average of 100 cells per field. Differentiated cells were counted by visual examination of the field; only cells that had at least one neurite with a length equal to the cell body diameter were counted, and were then expressed as a percentage of the total cells in the field. Counting was performed in a blinded manner. Data were expressed as a percentage of control group (NGF alone).

Immunocytochemistry. Cells were fixed for $30 \mathrm{~min}$ at room temperature (RT), with 4\% paraformaldehyde, permeabilized with $0.2 \%$ Triton and then blocked with $5 \%$ normal horse serum, in $0.1 \mathrm{~m}$ phosphate-buffer saline for $1 \mathrm{~h}$, to reduce nonspecific binding. Cells were incubated overnight at $4{ }^{\circ} \mathrm{C}$ with anti-microtubule-associated protein 2 (MAP-2) antibodies (1:1000 dilution in blocking solution, Chemicon International, Temecula, CA, USA). Immunolabeling was visualized with secondary antibodies conjugated to Alexa-488 (1:1000; Invitrogen, Carlsbad, CA, USA). MAP-2 immunocytochemistry was visualized by fluorescence microscopy (Axiovert 200, Carl Zeiss, Oberkochen, Germany).

Differential two-dimensional gel electrophoresis and MALDI-TOF MS analysis. In the presence of NGF $\left(2.5 \mathrm{ng} \mathrm{ml}^{-1}\right), \mathrm{PC} 12$ cells were either treated or not treated with aripiprazole $(1.0 \mu \mathrm{m})$. After four days, cells were suspended in Laemmli lysis buffer, and two-dimensional gel electrophoresis was performed. The spots of interest were analyzed using MALDI-TOF MS (Voyager-DE STR, Applied Biosystems, Carlsbad, CA, USA), as reported previously. $^{22,23}$

Western blot analysis. PC12 cells were washed with PBS and lysed in Laemmli lysis buffer. Aliquots $(30 \mu \mathrm{g})$ of protein were measured using the DC protein assay kit (Bio-Rad, Hercules, CA, USA) and incubated for $5 \mathrm{~min}$ at $95^{\circ} \mathrm{C}$, with an equal volume of $125 \mathrm{~mm}$ Tris/ $\mathrm{HCl}, \mathrm{pH} 6.8,20 \%$ glycerol, $0.1 \%$ bromophenol blue, $10 \% \beta$-mercaptoethanol, $4 \%$ sodium dodecyl sulfate, and subjected to sodium dodecyl sulfate polyacrylamide gel electrophoresis, using $7.5 \%$ mini-gels (Mini Protean II; Bio-Rad). Proteins were transferred onto polyvinylidene difluoride (PVDF) membranes using a Trans Blot Mini Cell (Bio-Rad). For immunodetection, the blots were blocked for $1 \mathrm{~h}$ in TBST (50 mm Tris/ $\mathrm{HCl}, \mathrm{pH} 7.8,0.13 \mathrm{M} \mathrm{NaCl}$, $0.1 \%$ Tween 20 ) containing $5 \%$ nonfat dry milk at RT, followed by incubation with rabbit anti-HSP90 $\alpha$ antibody (1:2000, ab2928, Abcam, Cambridge, UK), overnight at $4{ }^{\circ} \mathrm{C}$, in 5\% TBST blocking buffer. The blots were washed five times with TBST. Incubation with the secondary antibody (GE Healthcare Bioscience, Buckinghamshire, UK) was performed for $1 \mathrm{~h}$, at RT. After extensive washing, immunoreactivity was detected by ECL Prime Western Blotting Detection reagent (GE Healthcare Bioscience). Images were captured and immunoreactive bands were quantified using a Fuji LAS3000-mini imaging system (Fujifilm, Tokyo, Japan) with Multi Gauge software (Ver.3.0; Fujifilm). $\beta$-Actin immunoreactivity was used to monitor equal sample loading.

RNAi transfection. RNA interference (RNAi) gene expression knockdown studies were performed using the TriFECTa RNAi kit (Integrated DNA Technologies, Coralville, CA, USA) and protocol. Each 27 mer RNAi duplex was transfected into 
cells using Lipofectamine 2000 reagent (Invitrogen), following the manufacturer's guidelines. RNAi was purchased from Integrated DNA Technologies.

Statistical analysis. Data are expressed as mean values \pm standard error of the mean (s.e.m.). Statistical analysis was performed using one-way analysis of variance and the post hoc Bonferroni/Dunn test. $P$-values $<0.05$ were considered statistically significant.

\section{Results}

Role of 5-HT1A receptors in aripiprazole-mediated potentiation of NGF-induced neurite outgrowth. Aripiprazole $(0.001,0.01,0.1$ or $1.0 \mu \mathrm{m})$ in conjunction with NGF (2.5 $\left.\mathrm{ng} \mathrm{ml}^{-1}\right)$, significantly increased the number of cells with neurites, in a concentration-dependent manner (Figure 1a). The selective $5-\mathrm{HT}_{1 \mathrm{~A}}$ receptor antagonist WAY-100635 $(10 \mu \mathrm{M})$, significantly blocked the potentiation of NGF-induced neurite outgrowth by aripiprazole $(1.0 \mu \mathrm{m})$, although this inhibition was partial (Figure 1a). MAP-2 immunocytochemistry, which identifies neuronal markers, showed that aripiprazole $(1.0 \mu \mathrm{m})$ increased the number of cells with NGF (2.5 $\mathrm{ng} \mathrm{ml}^{-1}$ )-induced neurites (Figure $1 \mathrm{~b}$ ).

The selective $5-\mathrm{HT}_{1 \mathrm{~A}}$ receptor agonist $8 \mathrm{OH}-\mathrm{DPAT}(10 \mu \mathrm{m})$ significantly increased the number of cells with neurites induced by NGF, although the effect was less potent than that of aripiprazole (Figure 1c). In contrast, dopamine $D_{2}$ receptor antagonist sulpiride $(10 \mu \mathrm{m})$ failed to potentiate neurite outgrowth in the presence of NGF and aripiprazole (Figure 1d). Furthermore, sulpiride $(10 \mu \mathrm{m})$ alone did not alter NGF-induced neurite outgrowth in PC12 cells (Figure 1d). Collectively, these findings suggest that activation at $5-\mathrm{HT}_{1 \mathrm{~A}}$ receptors, as opposed to dopamine $D_{2}$ receptors, may play a partial role in the mechanisms of aripiprazole-induced neurite outgrowth.

Role of $\mathrm{IP}_{3}$ receptors and intracellular $\mathrm{Ca}^{2+}$ on the potentiation of NGF-induced neurite outgrowth by aripiprazole. $\mathrm{IP}_{3}$ receptors on the $\mathrm{ERs}$ are part of the signaling pathway that promotes NGF-induced neurite outgrowth in PC12 cells. ${ }^{19-25}$ To investigate the involvement of $\mathrm{IP}_{3}$ receptors in aripiprazole's action on this outgrowth, we examined the effects of xestospongin C (a selective, reversible and membrane-permeable inhibitor of $\mathrm{IP}_{3}$ receptors) ${ }^{35}$ and $2-\mathrm{APB}^{36,37}$ on our culture system. Addition of xestospongin $\mathrm{C}(1.0 \mu \mathrm{m})$ or 2 -APB $(100 \mu \mathrm{m})$ with aripiprazole $(1.0 \mu \mathrm{M})$ significantly blocked the potentiation of NGF-induced neurite outgrowth (Figures $2 \mathrm{a}$ and $\mathrm{b}$ ). Neither xestospongin $\mathrm{C}$ $(1.0 \mu \mathrm{M})$ nor 2 -APB $(100 \mu \mathrm{m})$ in the absence of aripiprazole promoted NGF-induced neurite outgrowth in PC12 cells (Figures 2a and b).

To assess how intracellular $\mathrm{Ca}^{2+}$ impacts on this system, we examined the effects of the BAPTA-AM, a $\mathrm{Ca}^{2+}$ chelator, ${ }^{25,38,39}$ on the potentiation of NGF-induced neurite outgrowth by aripiprazole $(1.0 \mu \mathrm{m})$. BAPTA-AM $(5.0 \mu \mathrm{m})$ significantly blocked the potentiation of NGF-induced neurite outgrowth by aripiprazole $(1.0 \mu \mathrm{M})$ (Figure $2 \mathrm{c})$. In addition, BAPTA-AM $(5.0 \mu \mathrm{m})$ also produced the same effect. A lactate dehydrogenase assay showed that BAPTA-AM $(5.0 \mu \mathrm{M})$ was
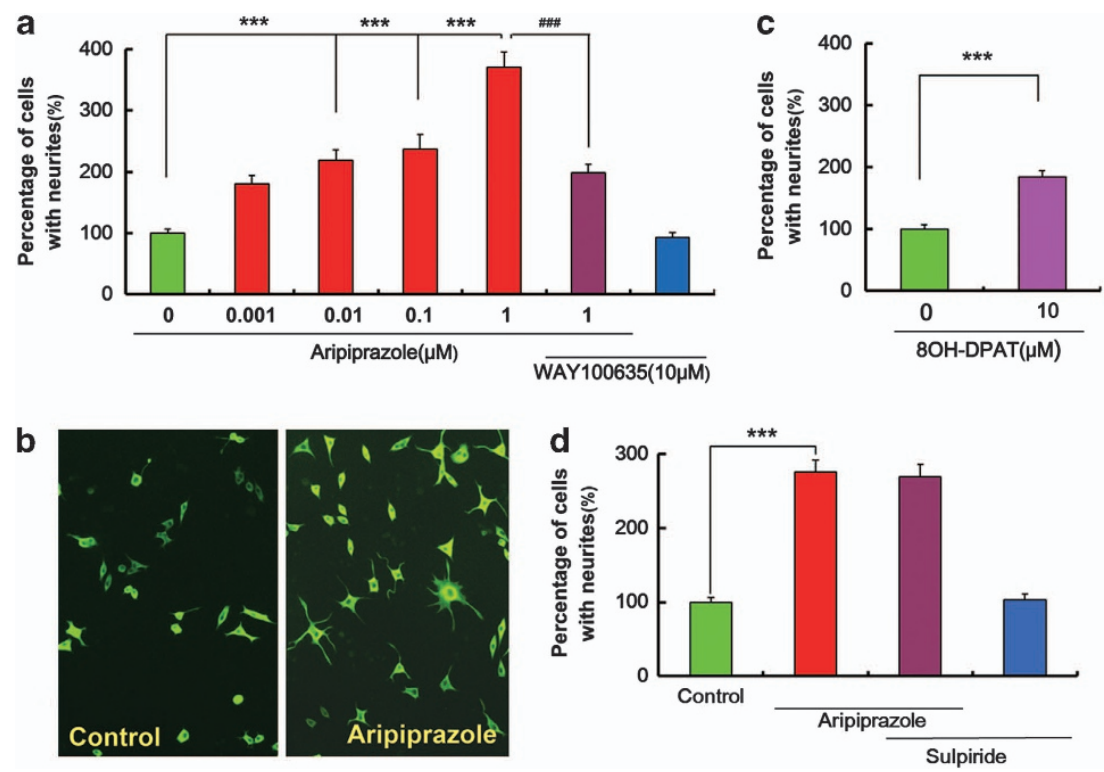

Figure 1 Aripiprazole potentiated nerve growth factor (NGF)-induced neurite outgrowth. (a) Effects of aripiprazole on NGF-induced neurite outgrowth in PC12 cells. Aripiprazole $(0.001,0.01,0.1$ or $1.0 \mu \mathrm{m})$ potentiated NGF-induced neurite outgrowth in PC12 cells, in a concentration-dependent manner. The selective 5-hydroxytryptamine $\left(5-\mathrm{HT}_{1 \mathrm{~A}}\right)$ receptor antagonist WAY-100635 $(10 \mu \mathrm{m})$ blocked the effects of aripiprazole. Data show the mean \pm s.e.m. $(n=7-19)$. (b) Representative photographs of microtubule-associated protein 2 (MAP-2) immunocytochemistry in PC12 cells. Control: NGF (2.5 ng ml${ }^{-1}$ ) alone, Aripiprazole: NGF $\left(2.5 \mathrm{ng} \mathrm{ml}^{-1}\right)+$ aripiprazole (1.0 $\left.\mu \mathrm{m}\right)$. (c) Selective 5- $\mathrm{HT}_{1 \mathrm{~A}}$ receptor agonist $8 \mathrm{OH}$-DPAT $(( \pm)$-8-hydroxy-2-dipropylaminotetralin hydrobromide) $(10 \mu \mathrm{m})$ potentiated NGF-induced neurite outgrowth. Data show the mean \pm s.e.m. $(n=12)$. (d) The dopamine $D_{2}$ receptor antagonist sulpiride $(10 \mu \mathrm{m})$ had no effect on aripiprazole and NGF-induced neurite outgrowth. ${ }^{* * *} P<0.001$ as compared with the control (NGF $\left(2.5 \mathrm{ng} \mathrm{ml}^{-1}\right)$ alone group). ${ }^{* * *} \mathrm{P}<0.001$ as compared with NGF $\left(2.5 \mathrm{ng} \mathrm{ml}^{-1}\right)+$ aripiprazole $(1.0 \mu \mathrm{m})$ group. The data show the mean \pm s.e.m. $(n=12)$. 

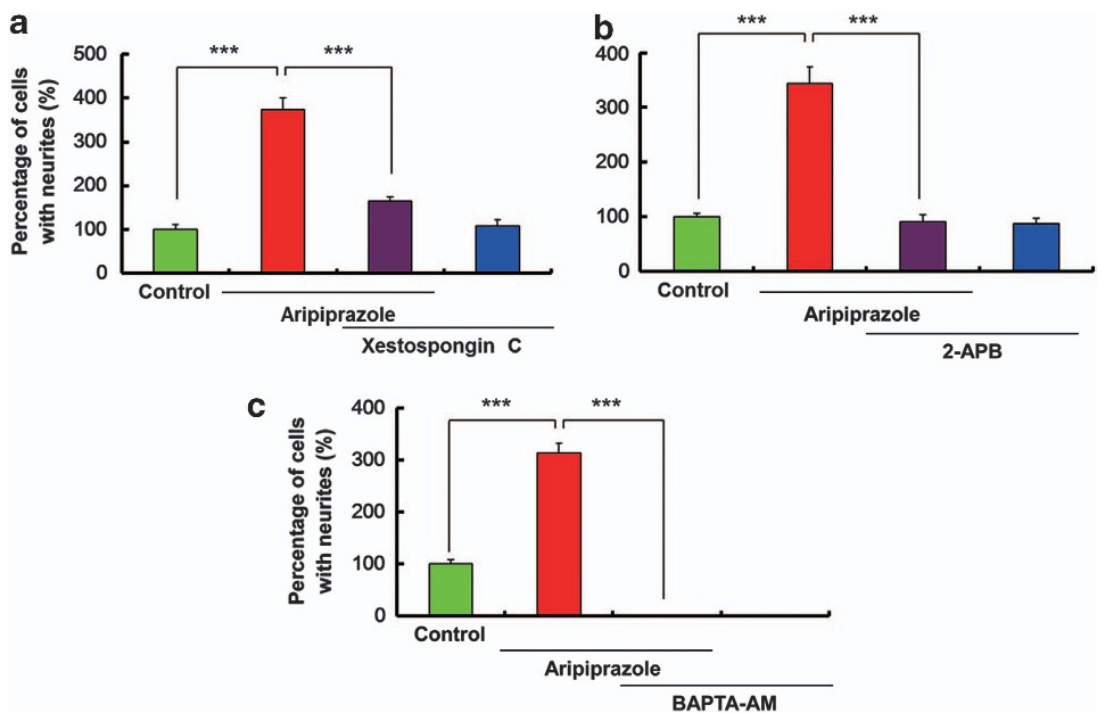

Figure 2 Effects of the inositol 1,4,5-triphosphate $\left(\mathrm{IP}_{3}\right)$ receptor antagonists and an intracellular $\mathrm{Ca}^{2+}$ chelator on the potentiation of nerve growth factor (NGF)-induced neurite outgrowth by aripiprazole. $(\mathbf{a}, \mathbf{b})$ The potentiating effects of aripiprazole $(1.0 \mu \mathrm{m})$ on NGF-induced neurite outgrowth were antagonized by the selective $\mathrm{IP}_{3}$ receptor antagonists, xestospongin $\mathrm{C}(1.0 \mu \mathrm{m})$ and 2-aminoethoxydiphenyl borate (2-APB) $(10 \mu \mathrm{M})$. Neither xestospongin $\mathrm{C}(1.0 \mu \mathrm{m})$ nor 2-APB $(100 \mu \mathrm{m})$ alone altered NGF-induced neurite outgrowth. Data show the mean \pm s.e.m. $(n=12)$. ${ }^{* \star *} P<0.001$ as compared with the control (NGF $\left(2.5 \mathrm{ng} \mathrm{ml}^{-1}\right)$ alone group). (c) BAPTA-AM (5.0 $\left.\mu \mathrm{m}\right)$ significantly blocked the effects of aripiprazole on NGF-induced neurite outgrowth. Data show the mean \pm s.e.m. $(n=12) .{ }^{* \star} P<0.001$ as compared with the control (NGF $\left(2.5 \mathrm{ng}\right.$ ml $\left.{ }^{-1}\right)$ alone group).
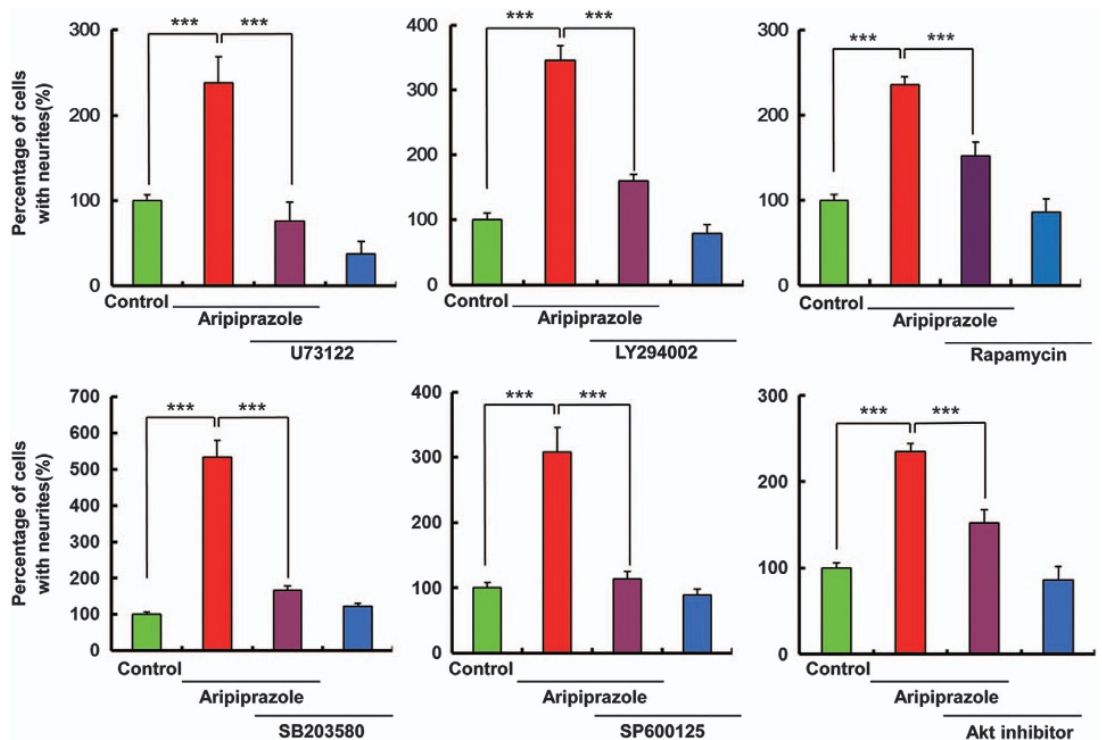

Figure 3 Effects of PLC- $\gamma$, PI3K, mammalian target of rapamycin (mTOR), p38MAPK, c-Jun N-terminal kinase (JNK) and Akt inhibition on potentiation of nerve growth factor (NGF)-induced neurite outgrowth by aripiprazole. The potentiating effects of aripiprazole (1.0 $\mu \mathrm{m})$ on NGF $\left(2.5 \mathrm{ng} \mathrm{ml}^{-1}\right)$-induced neurite outgrowth were antagonized by the PLC- $\gamma$ inhibitor (U73122; $1.0 \mu \mathrm{m}$ ), the PI3K inhibitor (LY294002; $10 \mu \mathrm{M})$, mTOR inhibitor (rapamycin; $5 \mu \mathrm{m}$ ), the p38MAPK inhibitor (SB203580; $10 \mu \mathrm{m})$, the JNK inhibitor (SP600125; $10 \mu \mathrm{M})$ and Akt inhibitor $(1.0 \mu \mathrm{M}) .{ }^{* \star \star} P<0.001$ as compared with the control (NGF $\left(2.5 \mathrm{ng} \mathrm{ml}^{-1}\right)$ alone group). Data show the mean \pm s.e.m. $(n=12)$.

not cytotoxic to PC12 cells (data not shown). These findings demonstrate that intracellular $\mathrm{Ca}^{2+}$ signaling is necessary for NGF-induced neurite outgrowth in PC12 cells, with or without aripiprazole.

Role of signaling molecules proximal to TrkA, on the potentiation of NGF-induced neurite outgrowth by aripiprazole. In cells, the signaling molecules PLC- $\gamma$, PI3K, mTOR, p38 MAPK, JNK and Akt are activated by
NGF. ${ }^{19,21-23,40-47}$ We examined the effects of specific inhibitors for these molecules on neurite outgrowth. The PLC- $\gamma$ inhibitor, U73122 (1.0 $\mu \mathrm{M})$, PI3K inhibitor, LY294002 $(10 \mu \mathrm{M}), \mathrm{mTOR}$ inhibitor (rapamycin; $5.0 \mu \mathrm{M})$, p38 MAPK

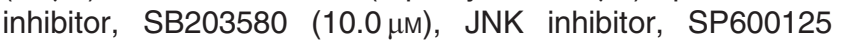
$(10 \mu \mathrm{M})$ and Akt inhibitor $(1.0 \mu \mathrm{M})$ significantly blocked aripiprazole's potentiation of NGF-induced neurite outgrowth (Figure 3). In contrast, these inhibitors alone could not potentiate NGF-induced neurite outgrowth (Figure 3). 

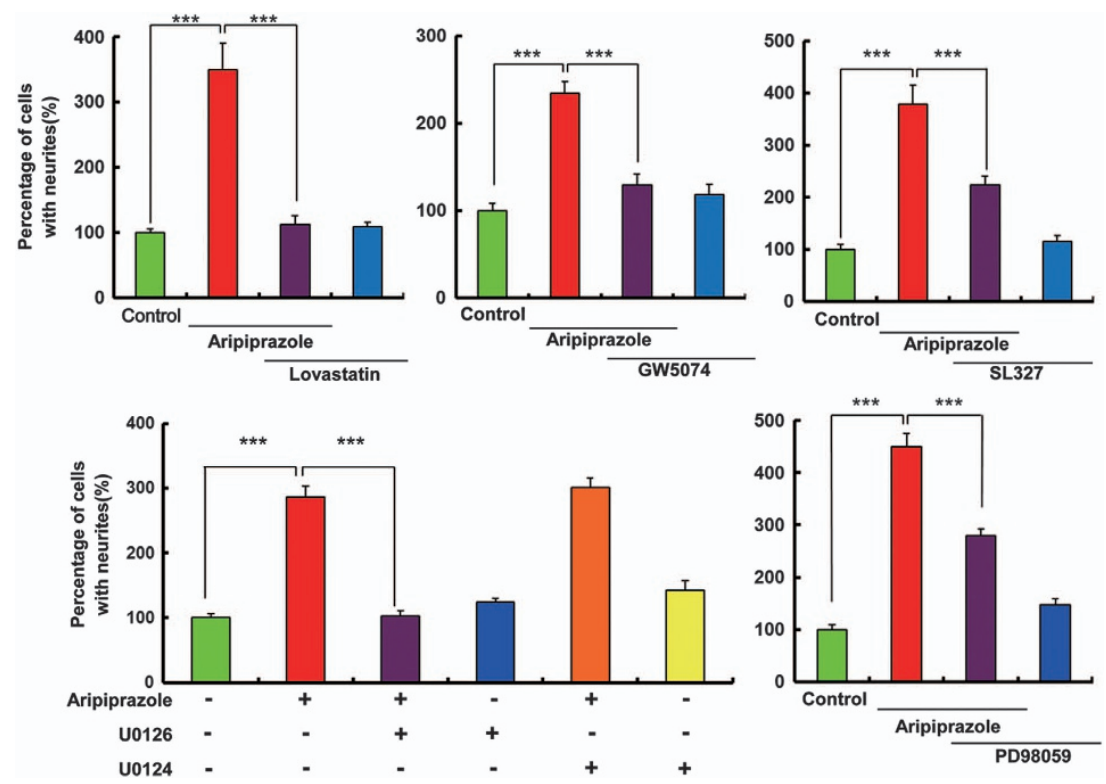

Figure 4 Effects of Ras, Raf, MEK1/2 and MAPK inhibition on potentiation of nerve growth factor (NGF)-induced neurite outgrowth by aripiprazole. The potentiating effects of aripiprazole $(1.0 \mu \mathrm{M})$ on NGF-induced neurite outgrowth were antagonized by the Raf inhibitor (GW5074; $5 \mu \mathrm{M}$ ), Ras inhibitor (lovastatin; $1 \mu \mathrm{M})$, MEK inhibitor (U0126; $10 \mu \mathrm{M})$, MEK1/2 inhibitor (SL327; $10 \mu \mathrm{M}$ ) and MAPK inhibitor (PD98059; $10 \mu \mathrm{M})$. In contrast, U0124 (10 $\mu \mathrm{M})$, an inactive inhibitor of U0126, did not alter the number of cells with neurites after aripiprazole treatment. Data show the mean \pm s.e.m. $(n=8-18) .{ }^{* \star} P<0.001$ as compared with the control (NGF $\left(2.5 \mathrm{ng} \mathrm{ml}^{-1}\right)$ alone group).

Role of the Ras/Raf/ERK/MAPK pathways in the potentiation of NGF-induced neurite outgrowth by aripiprazole. The Ras/Raf/ERK/MAPK pathways are reported to be involved in NGF-induced neurite outgrowth. ${ }^{19,21-23,41,42}$ Therefore, we examined the effects of inhibition on this pathway in the presence of aripiprazole. Inhibitors of Ras, Raf, MEK, MEK1/2 and MAPK (lovastatin; $1.0 \mu \mathrm{M}, \mathrm{GW} 5074$; $5.0 \mu \mathrm{m}$, U0126; $10 \mu \mathrm{M}$, SL327; $10 \mu \mathrm{M}$ and PD98059; $10 \mu \mathrm{M}$, respectively ) significantly blocked potentiation of NGFinduced neurite outgrowth by aripiprazole $(1.0 \mu \mathrm{M})$ (Figure 4). In contrast, U0124 $(10 \mu \mathrm{M})$, an inactive inhibitor of U0126, did not alter neurite outgrowth potentiation. Furthermore, none of these inhibitors altered NGF-induced neurite outgrowth in PC12 cells on their own (Figure 4).

Role of Hsp90 $\alpha$ in the potentiation of NGF-induced neurite outgrowth by aripiprazole. To investigate novel molecular targets for aripiprazole's potentiation of NGFinduced neurite outgrowth, we performed two-dimensional gel electrophoresis and analyzed the proteomics. We identified the heat shock protein Hsp90 $\alpha$ as being differentially expressed between control PC12 cells treated with NGF (2.5 $\left.\mathrm{ng} \mathrm{ml}^{-1}\right)$ and those treated with NGF $\left(2.5 \mathrm{ng} \mathrm{ml}^{-1}\right)$ and aripiprazole $(1.0 \mu \mathrm{m})$. Apriprazole treatment significantly increased Hsp90 $\alpha$ expression in PC12 cells (Figure 5a).

To interrogate the proposed link between aripiprazole treatment, elevated $\mathrm{Hsp} 90 \alpha$ production and the potentiation of NGF-induced neurite outgrowth, we treated PC12 cells with Hsp90 $\alpha$ RNAi. RNAi serves as a gene silencing mechanism, thereby reducing expression of $\mathrm{Hsp} 90 \alpha$ protein. As shown in Figure $5 \mathrm{a}$, increases in $\mathrm{Hsp} 90 \alpha$ protein expression by aripiprazole $(1.0 \mu \mathrm{m})$ were significantly blocked by treatment with $\mathrm{Hsp} 90 \alpha \mathrm{RNAi}$, but not by the negative control of $\mathrm{Hsp} 90 \alpha$
RNAi. In the absence of aripiprazole, treatment with $\mathrm{Hsp} 90 \alpha$ RNAi or negative control of $\mathrm{Hsp} 90 \alpha$ RNAi did not alter basal levels of Hsp90 $\alpha$ protein (Figure 5a). Furthermore, the potentiating effects of aripiprazole $(1.0 \mu \mathrm{m})$ on NGF-induced neurite outgrowth were significantly attenuated by treatment with $\mathrm{Hsp} 90 \alpha \mathrm{RNAi}$, but not the negative control of $\mathrm{Hsp} 90 \alpha$ (Figure 5b). Treatment with Hsp90 $\alpha$ RNAi or the negative control of Hsp90 $\alpha$ RNAi alone did not alter NGF-induced neurite outgrowth in PC12 cells (Figure 5b).

\section{Discussion}

This study found that aripiprazole potentiated NGF-induced neurite outgrowth in PC12 cells, mediating this at the molecular level, at least in part, via an increase in Hsp90 $\alpha$ protein. Aripiprazole, an atypical antipsychotic drug, licensed for use in a variety of psychiatric disorders, acts through partial agonism of dopamine $\mathrm{D}_{2}$ and $5-\mathrm{HT}_{1 \mathrm{~A}}$ receptors, and antagonism of $5-\mathrm{HT}_{2 \mathrm{~A}}$ receptors. We found that aripiprazole potentiated NGF-induced neurite outgrowth in PC12 cells, and that this potentiation could be partially blocked by the selective $5-\mathrm{HT}_{1 \mathrm{~A}}$ receptor antagonist WAY-100635, but not the dopamine $D_{2}$ receptor antagonist sulpiride. The selective $5-\mathrm{HT}_{1 \mathrm{~A}}$ receptor agonist $8 \mathrm{OH}$-DPAT also potentiated NGFinduced neurite outgrowth in PC12 cells, although to a lesser degree than aripiprazole. This result is in agreement with findings from human neuroblastoma SK-N-SH cells, which showed that $8 \mathrm{OH}$-DPAT increased neurite outgrowth that could be blocked by the selective $5-\mathrm{HT}_{1 \mathrm{~A}}$ receptor antagonist WAY-100169. ${ }^{48}$ Thus, it is likely that activation of $5-\mathrm{HT}_{1 \mathrm{~A}}$ receptors plays a role in the mechanisms that lead to aripiprazole-driven enhancement of NGF-induced neurite outgrowth. 
a

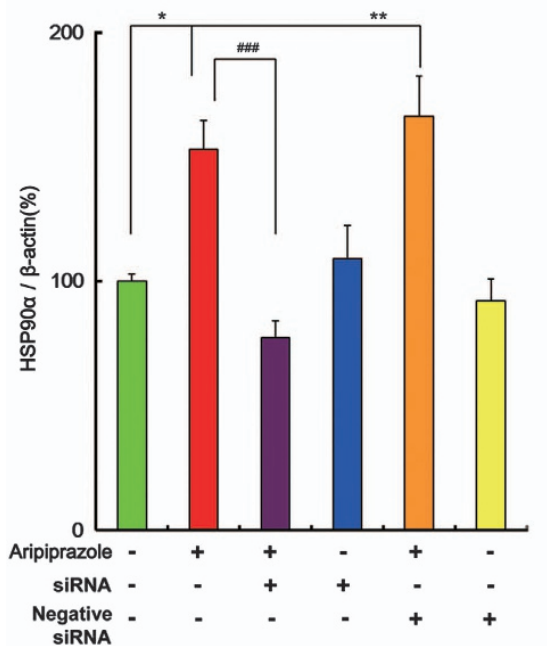

b

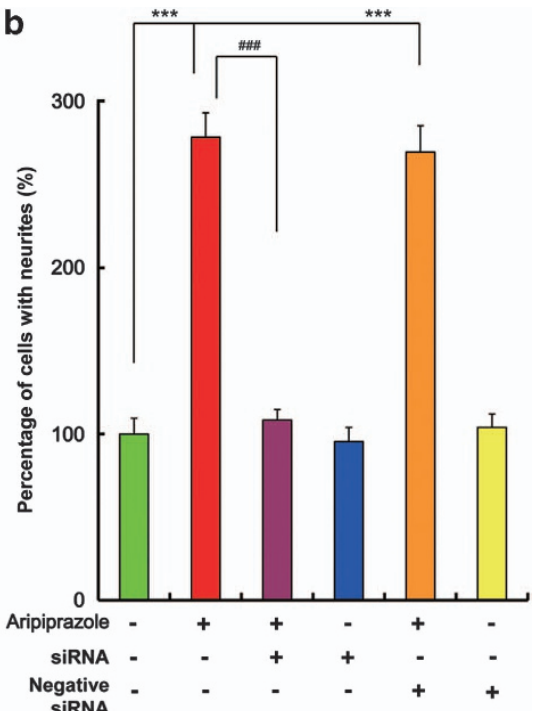

Figure 5 An increase in Hsp90 $\alpha$ protein is required for aripiprazole-induced potentiation of nerve growth factor (NGF)-induced neurite outgrowth. (a) The potentiating effects of aripiprazole $(1.0 \mu \mathrm{M})$ on Hsp90 $\alpha$ protein levels were significantly antagonized by treatment with $\mathrm{Hsp} 90 \alpha$ RNA interference (RNAi), but not the negative RNAi. In contrast, neither Hsp90 $\alpha$ RNAi nor negative RNAi alone altered levels of $\mathrm{Hsp} 90 \alpha$ protein in the control (NGF $\left(2.5 \mathrm{ng} \mathrm{ml}^{-1}\right)$-treated) group. Data show the mean \pm s.e.m. $(n=6) .{ }^{* \star *} P<0.001$ as compared with the aripiprazole $(1.0 \mu \mathrm{m})$ group. (b) The potentiating effects of aripiprazole $(1.0 \mu \mathrm{m})$ on NGF-induced neurite outgrowth were significantly antagonized by treatment with $\mathrm{Hsp} 90 \propto$ RNAi, but not negative RNAi. Neither Hsp90 $\alpha$ RNAi nor negative RNAi alone altered NGF $\left(2.5 \mathrm{ng} \mathrm{ml}^{-1}\right)$-induced neurite outgrowth. Data show the mean \pm s.e.m. $(n=8) .{ }^{* \star} P<0.001$ as compared with the aripiprazole $(1.0 \mu \mathrm{M})$ group.

Nagai et al..$^{49}$ reported that aripiprazole ameliorates cognitive deficits in mice after repeated dosing with the $\mathrm{N}$-methyl-D-aspartate receptor antagonist, phencyclidine, and that this effect is antagonized by co-treatment with WAY100635 , a $5-\mathrm{HT}_{1 \mathrm{~A}}$ receptor antagonist, suggesting a role for $5-\mathrm{HT}_{1 \mathrm{~A}}$ receptors. Given that $5-\mathrm{HT}_{1 \mathrm{~A}}$ receptor function is implicated in schizophrenia related cognitive impairment, ${ }^{50-53}$ activation of this receptor by aripiprazole may confer a beneficial effect in these patients. ${ }^{54}$ Interestingly, aripiprazole attenuated established behavioral sensitization in rats after repeated administration of the stimulant methamphetamine. ${ }^{55}$ This effect was antagonized by pretreatment with the $5-\mathrm{HT}_{1 \mathrm{~A}}$ receptor antagonist WAY-100169, suggesting that aripiprazole acts through $5-\mathrm{HT}_{1 \mathrm{~A}}$ receptors in attenuating methamphetamine-induced behavioral sensitization. ${ }^{55}$ Since methamphetamine-induced behavioral sensitization is an animal model for both stimulant-induced psychosis and relapse vulnerability of schizophrenia, it is logical to reason that the therapeutic actions of aripiprazole are mediated by activation of $5-\mathrm{HT}_{1 \mathrm{~A}}$ receptors.

$\mathrm{IP}_{3}$ is a ubiquitous second messenger responsible for the release of $\mathrm{Ca}^{2+}$ from the ER, a tightly controlled process which is critically important for maintaining cellular functions, including cell growth, and neurite outgrowth. ${ }^{56,57}$ In this study, we found that $\mathrm{IP}_{3}$ receptor antagonists (xestospongin $\mathrm{C}$ and 2-APB), and the intracellular $\mathrm{Ca}^{2+}$ chelator, BAPTA-AM, significantly blocked potentiation of NGF-induced neurite outgrowth by aripiprazole, indicating involvement of $\mathrm{IP}_{3}$ receptors and intracellular $\mathrm{Ca}^{2+}$ signaling on NGF-induced neurite outgrowth. Previously, we reported that several drugs utilize $\mathrm{IP}_{3}$ receptors to potentiate NGF-induced neurite outgrowth. ${ }^{19-25}$ It is reasonable to conclude that $\mathrm{Ca}^{2+}$ signaling via $\mathrm{IP}_{3}$ receptors plays a key role in the mechanism underlying aripiprazole's potentiation of NGF-induced neurite outgrowth.
From our results, we postulate that several common cellular, signaling pathways might be responsible for promoting aripiprazole's potentiation of NGF-induced neurite outgrowth. NGF binds to the high-affinity tyrosine receptor TrkA, initiating several cellular signaling pathways, affecting both morphological and transcriptional targets. ${ }^{19,21-23,41,42}$ Signaling molecules, including PLC- $\gamma$, PI3K, Akt, mTOR, p38 MAPK and JNK, are activated upon the addition of NGF. ${ }^{40}$ PLC- $\gamma$ catalyzes the hydrolysis of phosphatidylinositol-4,5-bisphosphate $\left(\mathrm{PIP}_{2}\right)$ to diacylglycerol and $\mathrm{IP}_{3}$. Diacylglycerol activates protein kinase $C$, and $\mathrm{IP}_{3}$ promotes transient release of $\mathrm{Ca}^{2+}$ from the $\mathrm{ER}$ via stimulation at $\mathrm{IP}_{3}$ receptors. Thus, the pathway via PLC- $\gamma$ is responsible for NGF-induced neurite outgrowth. ${ }^{19,21-23,58}$ Furthermore, PI3K stimulation promotes neurite outgrowth in $\mathrm{PC} 12$ cells. ${ }^{19,21-23,47}$ In this study, we found that selective inhibitors of these cellular signaling pathways significantly blocked potentiation of NGF-induced neurite outgrowth by aripiprazole. In addition, we found that specific inhibitors of the Ras/Raf/MEK/MAPK pathway also significantly blocked the potentiation of NGF-induced neurite outgrowth by aripiprazole. These combined findings suggest that common cellular pathways, including PLC- $\gamma$, PI3K, Akt, mTOR, p38MAPK and JNK and Ras/Raf/MEK/MAPK, contribute to the potentiation of NGF-induced neurite outgrowth by aripiprazole.

Considering the function of the aforementioned signaling molecules in regulating protein synthesis-dependent learning and memory, ${ }^{59}$ aripiprazole-driven changes in these pathways may promote synthesis of new proteins associated with neurite outgrowth. Through proteomic analysis, we identified differential expression of $\mathrm{Hsp} 90 \alpha$, a molecular cytoplasmic chaperone, as a novel protein linked to neurite outgrowth. To our knowledge, this is the first report demonstrating a requirement for aripiprazole-driven increases in Hsp90 $\alpha$ 
protein for neurite outgrowth. Hsp90 is an essential molecular chaperone, ubiquitously active in many signaling and other cellular pathways. ${ }^{32-34}$ Accumulating evidence suggests that Hsp90 plays a key role in the assembly of a number of protein complexes, ${ }^{34}$ which could include those required for antipsychotic drug action. Previously, Ishimoto et al. ${ }^{60}$ reported that the Hsp90 protein promoted neurite formation in vitro, in chick telencephalic and spinal neurons. We found that another 5- $\mathrm{HT}_{1 \mathrm{~A}}$ receptor agonist, $8 \mathrm{OH}$-DPAT also increased $\mathrm{Hsp} 90 \alpha$ protein levels in PC12 cells, although its effect was less pronounced compared with aripiprazole (Supplementary Figure 1). This suggests that $5-\mathrm{HT}_{1 \mathrm{~A}}$ receptor activation contributes to increased $\mathrm{Hsp} 90 \alpha$ protein, although the precise mechanisms underlying this expression are not known. It would appear that aripiprazole-driven increases in $\mathrm{Hsp} 90 \alpha$ protein potentiate NGF-induced neurite outgrowth although it is unclear how enhanced Hsp90 $\alpha$ expression contributes to its therapeutic effect in psychiatric disorders. Taken together, it is likely that induction of Hsp90 $\alpha$ levels in the brain may have beneficial effects in patients with psychiatric disorders. It would, therefore, be of great interest to study the effect of aripiprazole on serum Hsp90 $\alpha$ levels, in patients with psychiatric disorders.

Induction of Hsp90 $\alpha$ in the hippocampal CA1 cells after transient global ischemia may suggest a neuroprotective role of $\mathrm{Hsp} 90 \alpha$ in ischemia-induced cell death. ${ }^{61}$ It may be that molecules that increase Hsp90 $\alpha$ protein levels may confer a therapeutic effect in psychiatric and neurodegenerative conditions, with altered neurite outgrowth. Furthermore, it is reported that the antibody to HSP90 was detected in the serum of a subset of patients with schizophrenia, suggesting the role of the autoimmunity to HSP90 in the pathogenesis and development of schizophrenia. ${ }^{62}$ In order to confirm the role of HSP90 in the pathogenesis of schizophrenia, the detection of antibodies to HSP90 in the cerebrospinal fluid of patients would be needed.

In conclusion, our results suggest that aripiprazole potentiates NGF-induced neurite outgrowth in PC12 cells, by $\mathrm{Ca}^{2+}$ signaling, via the $\mathrm{IP}_{3}$ receptors and common cellular signaling pathways. Furthermore, the increased expression of Hsp90 $\alpha$ protein induced by aripiprazole, may drive potentiation of NGF-induced neurite outgrowth. This suggests that Hsp90 $\alpha$ may represent a novel effector protein for the therapeutic action of aripiprazole.

\section{Conflict of interest}

The authors declare no conflict of interest.

Acknowledgements. This study was supported by a Grant-in-Aid for Young Scientists (B) (to TI), a Grant-in-Aid for Scientific Research (B) (to KH) from Japan Society for the Promotion of Science (JSPS), and a Grant-in-Aid for Scientific Research on Innovative Areas (to $\mathrm{KH}$ ) from the Ministry of Education, Culture, Sports, Science and Technology (MEXT), Japan.

1. Goodnick PJ, Jerry JM. Aripiprazole: profile on efficacy and safety. Expert Opin Pharmacother 2002; 3: 1773-1781.

2. Keck PE Jr., McElroy SL. Aripiprazole: a partial dopamine $D_{2}$ receptor agonist antipsychotic. Expert Opin Investig Drugs 2003; 12: 655-662.
3. Scherk H, Pajonk FG, Leucht S. Second-generation antipsychotic agents in the treatment of acute mania: a systematic review and meta-analysis of randomized controlled trials. Arch Gen Psychiatry 2007; 64: 442-455.

4. Ketter TA. Monotherapy versus combined treatment with second-generation antipsychotics in bipolar disorder. J Clin Psychiatry 2008; 69(Suppl 5): 9-15.

5. Khan A. Current evidence for aripiprazole as augmentation therapy in major depressive disorder. Expert Rev Neurother 2008; 8: 1435-1447.

6. Fountoulakis KN, Vieta E, Schmidt F. Aripiprazole monotherapy in the treatment of bipolar disorder: a meta-analysis. J Affect Disord 2011; 133: 361-370.

7. Yildiz A, Vieta E, Leucht S, Baldessarini RJ. Efficacy of antimanic treatments: metaanalysis of randomized, controlled trials. Neuropsychopharmacology 2011; 36: 375-389.

8. Marcus RN, Owen R, Kamen L, Manos G, McQuade RD, Carson WH et al. A placebocontrolled, fixed-dose study of aripiprazole in children and adolescents with irritability associated with autistic disorder. J Am Acad Child Adolesc Psychiatry 2009; 48: 1110-1119.

9. Erickson CA, Stigler KA, Posey DJ, McDougle CJ. Aripiprazole in autism spectrum disorders and fragile $X$ syndrome. Neurotherapeutics 2010; 7: 258-263.

10. Lawler CP, Prioleau C, Lewis MM, Mak C, Jiang D, Schetz JA et al. Interactions of the novel antipsychotic aripiprazole (OPC-14597) with dopamine and serotonin receptor subtypes. Neuropsychopharmacology 1999; 20: 612-627.

11. Shapiro DA, Renock S, Arrington E, Chiodo LA, Liu LX, Sibley DR et al. Aripiprazole, a novel atypical antipsychotic drug with a unique and robust pharmacology. Neuropsychopharmacology 2003; 28: 1400-1411.

12. Burris KD, Molski TF, Xu C, Ryan E, Tottori K, Kikuchi T et al. Aripiprazole, a novel antipsychotic, is a high-affinity partial agonist at human dopamine $D_{2}$ receptors. J Pharmacol Exp Ther 2002; 302: 381-389.

13. DeLeon A, Patel NC, Crismon ML. Aripiprazole: a comprehensive review of its pharmacology, clinical efficacy, and tolerability. Clin Ther 2004; 26: 649-666.

14. Newman-Tancredi A, Kleven MS. Comparative pharmacology of antipsychotics possessing combined dopamine $\mathrm{D}_{2}$ and serotonin $5-\mathrm{HT}_{1 \mathrm{~A}}$ receptor properties. Psychopharmacology (Berl) 2011; 216: 451-473.

15. Lu XH, Dwyer DS. Second-generation antipsychotic drugs, olanzapine, quetiapine, and clozapine enhance neurite outgrowth in PC12 cells via PI3K/AKT, ERK, and pertussis toxin-sensitive pathways. J Mol Neurosci 2005; 27: 43-64.

16. Williams B, Dwyer DS. Structure-based discovery of low molecular weight compounds that stimulate neurite outgrowth and substitute for nerve growth factor. J Neurochem 2009; 110: 1876-1884.

17. Lieberman JA, Bymaster FP, Meltzer HY, Deutch AY, Duncan GE, Marx CE et al. Antipsychotic drugs: comparison in animal models of efficacy, neurotransmitter regulation, and neuroprotection. Pharmacol Rev 2008; 60: 358-403.

18. Molteni R, Calabrese F, Racagni G, Fumagalli F, Riva MA. Antipsychotic drug actions on gene modulation and signaling mechanisms. Pharmacol Ther 2009; 124: 74-85

19. Nishimura T, Ishima T, lyo M, Hashimoto K. Potentiation of nerve growth factor-induced neurite outgrowth by fluvoxamine: role of sigma-1 receptors, $\mathrm{IP}_{3}$ receptors and cellular signaling pathways. PLoS One 2008; 3: e2558.

20. Ishima T, Nishimura T, lyo M, Hashimoto K. Potentiation of nerve growth factor-induced neurite outgrowth in $\mathrm{PC} 12$ cells by donepezil: role of sigma- 1 receptors and $\mathrm{IP}_{3}$ receptors. Prog Neuropsychopharmacol Biol Psychiatry 2008; 32: 1656-1659.

21. Minase $T$, Ishima $T$, Itoh $K$, Hashimoto $K$. Potentiation of nerve growth factor-induced neurite outgrowth by the ROCK inhibitor Y-27632: a possible role of $\mathrm{IP}_{3}$ receptors. Eur $\mathrm{J}$ Pharmacol 2010; 648: 67-73.

22. Hashimoto K, Ishima T. A novel target of action of minocycline in NGF-induced neurite outgrowth in PC12 cells: translation initiation factor elF4AI. PLoS One 2010; 5: e15430.

23. Hashimoto $\mathrm{K}$, Ishima $\mathrm{T}$. Neurite outgrowth mediated by translation elongation factor eEF1A1: a target for antiplatelet agent cilostazol. PLoS One 2011; 6: e17431.

24. Itoh K, Ishima T, Kehler J, Hashimoto K. Potentiation of NGF-induced neurite outgrowth in PC12 cells by papaverine: role played by PLC-gamma and $\mathrm{IP}_{3}$ receptors. Brain Res 2011; 1377: 32-40.

25. Ishima T, Hashimoto K. Potentiation of nerve growth factor-induced neurite outgrowth in PC12 cells by ifenprodil: role of sigma-1 and IP $\mathrm{P}_{3}$ receptors. PLoS One 2012; 7: e37989.

26. Koprivica V, Regardie K, Wolff C, Fernalld R, Murphy JJ, Kambayashi J et al. Aripiprazole protects cortical neurons from glutamate toxicity. Eur J Pharmacol 2011; 651: 73-76.

27. Morimoto RI. Regulation of the heat sjock transcriptional response: cross talk between a family of heat shock factors, molecular chaperones, and negative regulators. Genes Dev 1998; 12: 3788-3796.

28. Csermely P, Schnaider T, Soti C, Prohászka Z, Nardai G. The 90-kDa molecular chaperone family: structure, function, and clinical applications. A comprehensive review. Pharmacol Ther 1998; 79: 129-168.

29. Buchner J. Hsp90 \& Co. - a holding for folding. Trends Biochem Sci 1999; 24: 136-141.

30. Jolly $\mathrm{C}$, Morimoto RI. Role of the heat shock response and molecular chaperones in oncogenesis and cell death. J Natl Cancer Inst 2000; 92: 1564-1572.

31. Picard D. Heat-shock protein 90 , a chaperone for folding and regulation. Cell Mol Life Sci 2002; 59: 1640-1648.

32. Mollapour M, Neckers L. Post-translational modifications of Hsp90 and their contributions to chaperone regulation. Biochim Biophys Acta 2012; 1823: 648-655.

33. Hartson SD, Matts RL. Approaches for defining the Hsp90-dependent proteome. Biochim Biophys Acta 2012; 1823: 656-667. 
34. Makhnevych T, Houry WA. The role of Hsp90 in protein complex assembly. Biochim Biophys Acta 2012; 1823: 674-682.

35. Gafni J, Munsch JA, Lam TH, Catlin MC, Costa LG, Molinski TF et al. Xestospongins: potent membrane permeable blockers of the inositol 1,4,5-trisphosphate receptor. Neuron 1997; 19: 723-733

36. Maruyama T, Kanaji T, Nakade S, Kanno T, Mikoshiba K. 2APB, 2-aminoethoxydiphenyl borate, a membrane-penetrable modulator of ins $(1,4,5) \mathrm{P}_{3}$-induced $\mathrm{Ca}^{2+}$ release. J Biochem 1997; 122: 498-505.

37. Ma HT, Patterson RL, van Rossum DB, Birnbaumer L, Mikoshiba K, Gill DL. Requirement of the inositol trisphosphate receptor for activation of store-operated $\mathrm{Ca}^{2+}$ channels. Science 2000; 287: 1647-1651.

38. Williams EJ, Doherty P, Turner G, Reid RA, Hemperly JJ, Walsh FS. Calcium influx into neurons can solely account for cell contact-dependent neurite outgrowth stimulated by transfected L1. J Cell Biol 1992; 119: 883-892.

39. Takeshita M, Banno Y, Nakamura M, Otsuka M, Teramachi H, Tsuchiya T et al. The pivotal role of intracellular calcium in oxaliplatin-induced inhibition of neurite outgrowth but not cell death in differentiated PC12 cells. Chem Res Toxicol 2011; 24: 1845-1852.

40. Sofroniew MV, Howe CL, Mobley WC. Nerve growth factor signaling, neuroprotection, and neural repair. Annu Rev Neurosci 2001; 24: 1217-1281.

41. Chao MV. Neurotrophins and their receptors: a convergence point for many signalling pathways. Nat Rev Neurosci 2003; 4: 299-309.

42. Huang EJ, Reichardt LF. Trk receptors: roles in neuronal signal transduction. Annu Rev Biochem 2003; 72: 609-642.

43. Read DE, Gorman AM. Involvement of Akt in neurite outgrowth. Cell Mol Life Sci 2009; 66 2975-2984.

44. Zeng M, Zhou JN. Roles of autophagy and mTOR signaling in neuronal differentiation of mouse neuroblastoma cells. Cell Signal 2008; 20: 659-665.

45. Zheng J, Feng X, Hou L, Cui Y, Zhu L, Ma J et al. Latanoprost promotes neurite outgrowth in differentiated RGC-5 cells via the PI3K-Akt-mTOR signaling pathway. Cell Mol Neurobiol 2011; 31: 597-604

46. Okada K, Tanaka H, Temporin K, Okamoto M, Kuroda Y, Moritomo H et al. Akt/mammalian target of rapamycin signaling pathway regulates neurite outgrowth in cerebellar granule neurons stimulated by methylcobalamin. Neuroci Lett 2011; 495: 201-204.

47. Kimura K, Hattori S, Kabuyama Y, Shizawa Y, Takayanagi J, Nakamura S et al. Neurite outgrowth of PC12 cells is suppressed by wortmannin, a specific inhibitor of phosphatidylinositol 3-kinase. J Biol Chem 1994; 269: 18961-18967.

48. Fricker AD, Rios C, Devi LA, Gomes I. Serotonin receptor activation leads to neurite outgrowth and neuronal survival. Brain Res Mol Brain Res 2005; 138: 228-235.

49. Nagai $T$, Murai $R$, Matsui $K$, Kamei $H$, Noda $Y$, Furukawa $H$ et al. Aripiprazole ameliorates phencyclidine-induced impairment of recognition memory through dopamine $\mathrm{D}_{1}$ and serotonin $5-\mathrm{HT}_{1 \mathrm{~A}}$ receptors. Psychopharmacology (Berl) 2009; 202 315-328.
50. Sumiyoshi T, Park S, Jayathilake K, Roy A, Ertugrul A, Meltzer HY. Effect of buspirone, a serotonin $1 \mathrm{~A}$ partial agonist, on cognitive function in schizophrenia: a randomized, doubleblind, placebo-controlled study. Schizophr Res 2007; 95: 158-168.

51. Meltzer HY, Sumiyoshi T. Does stimulation of $5-\mathrm{HT}_{1 \mathrm{~A}}$ receptors improve cognition in schizophrenia? Behav Brain Res 2008; 195: 98-102.

52. Hagiwara H, Fujita Y, Ishima T, Kunitachi S, Shirayama Y, lyo M et al. Phencyclidineinduced cognitive deficits in mice are improved by subsequent subchronic administration of the antipsychotic drug perospirone: Role of serotonin $5-\mathrm{HT}_{1 \mathrm{~A}}$ receptors. Eur Neuropsychopharmacol 2008; 18: 448-454.

53. Yoshida T, lyo M, Hashimoto K. Recent advances in the potential therapeutic drugs for cognitive deficits in schizophrenia. Curr Psychiatry Rev 2012; 8: 140-150.

54. Riedel M, Spellmann I, Schennach-Wolff R, Musil R, Dehning S, Cerovecki A et al. Effect of aripiprazole on cognition in the treatment of patients with schizophrenia. Pharmacopsychiatry 2010; 43: 50-57.

55. Futamura T, Akiyama S, Suhino H, Forbes A, McQuade RD, Kikuchi T. Aripiprazole attenuates established behavioral sensitization induced by methamphetamine. Prog Neuro-Psychopharmacol Biol Psychiatrty 2010; 34: 1115-1119.

56. Berridge MJ. Inositol trisphosphate and calcium signaling. Nature 1993; 361: 315-325.

57. Iketani M, Imaizumi C, Nakamura F, Jeromin A, Mikoshiba K, Goshima Y et al. Regulation of neurite outgrowth mediated by neuronal calcium sensor-1 and inositol 1,4,5trisphosphate receptor in nerve growth cones. Neuroscience 2009; 161: 743-752.

58. Stephens RM, Loeb DM, Copeland TD, Pawson T, Greene LA, Kaplan DR et al. Trk receptors use redundant signal transduction pathways involving SHC and PLC- $\gamma 1$ to mediate NGF responses. Neuron 1994; 12: 691-705.

59. Costa-Mattioli M, Sossin WS, Klann E, Sonenberg N. Translational control of long-lasting synaptic plasticity and memory. Neuron 2009; 61: 10-26.

60. Ishimoto T, Kamei A, Koyanagi S, Nishide N, Uyeda A, Kasai M et al. HSP90 has neuritepromoting activity in vitro for telencephalic and spinal neurons of chick embryos. Biochem Biophys Res Commun 1998; 253: 283-287.

61. Kawagoe J, Abe K, Aoki M, Kogure K. Induction of HSP90 alpha heat shock mRNA after transient global ischemia in gerbil hippocampus. Brain Res 1993; 621: 121-125.

62. Kim JJ, Lee SJ, Toh KY, Lee CU, Lee C, Paik IH. Identification of antibodies to heat shock proteins $90 \mathrm{kDa}$ and $70 \mathrm{kDa}$ in patients with schizophrenia. Schizophrenia Res 2001; 52 127-135.

Translational Psychiatry is an open-access journal published by Nature Publishing Group. This work is licensed under the Creative Commons Attribution-NonCommercialShare Alike 3.0 Unported License. To view a copy of this license, visit http://creativecommons.org/licenses/by-nc-sa/3.0/

Supplementary Information accompanies the paper on the Translational Psychiatry website (http://www.nature.com/tp) 